\title{
Dissolution of Connective Tissue in Sodium Hypochlorite Alone and in Combination with $3 \%$ Hydrogen Peroxide
}

\author{
Disolución de Tejido Conectivo en Hipoclorito de Sodio solo \\ y en Combinación con Peróxido de Hidrógeno al $3 \%$.
}

Echeverri, D. \& Acuña, C.

ECHEVERRI, D. \& ACUÑA, C. Dissolution of connective tissue in sodium hypochlorite alone and in combination with $3 \%$ hydrogen peroxide. Int. J. Odontostomat., 6(3):263-266, 2012.

ABSTRACT: The aim was to evaluate the dissolution of porcine muscle using sodium hypochlorite in several concentrations and in combination with $3 \%$ hydrogen peroxide. Small pieces of porcine muscle were cut and their weight adjusted at $0.02 \mathrm{~g}$ to be submerged in $1 \mathrm{ml}$ of each test solution which was changed in 1 minute intervals until complete dissolution of the sample was observed. The 75 pieces of tissue were divided in 5 groups and different irrigant solutions were used as follows: Group 1, 5\% sodium hypochlorite (NaOCl 5\%). Group 2, 2.5\% sodium hypochlorite (NaOCl 2.5\%). Group $3,2.5 \%$ sodium hypochlorite and $3 \%$ hydrogen peroxide alternately ( $\mathrm{NaOCl} 2.5 \%+\mathrm{H} 2 \mathrm{O} 23 \%$ ). Group 4,3\% hydrogen peroxide $(\mathrm{H} 2 \mathrm{O} 2)$, and group 5 used saline $(\mathrm{NaCl} 0.9 \%)$ as a negative control. For $5 \%$ sodium hypochlorite the mean time until complete dissolution of the sample was 17.5 minutes. The mean time for group 2 was 18.5 , for group 3 was 64.6 minutes and for groups 4 and 5 there was no tissue dissolution after 120 minutes. To evaluate statistical significance ANOVA multi sample test was performed and Tukey post hoc test with significance level at $P=0.05$. Under the conditions of this study there were no significant differences with the use of sodium hypochlorite at $5 \%$ and $2.5 \%$ in terms of dissolution speed $(P=0.6)$. The combination of sodium hypochlorite and hydrogen peroxide alternately caused a statistical significant delay in the dissolution of porcine muscle $(\mathrm{P}<0.05)$. The combination of sodium hypochlorite and hydrogen peroxide does not offer any benefit in terms of speed of dissolution of connective necrotic tissue.

KEY WORDS: sodium hipochlorite, irrigating solution, hydrogen peroxide.

\section{INTRODUCTION}

Chemo-mechanical preparation of the root canal is one of the main objectives of endodontic therapy (Hata et al., 2001). Given the complex morphology of the root canal system, the achievement of this goal turns to be a challenge considering that endodontic files may contact only 35 to $53 \%$ of root canal walls, regardless of the instrumentation technique (Gulabivala et al., 2005). Therefore, the use of irrigant solutions reaching inaccessible areas of the root canal anatomy for reducing debris and microorganisms becomes essential (Andersen et al., 1992).

Endodontic irrigants clean and disinfect root canals by both, mechanical drag of microorganisms and debris and by chemical action dissolving cell membranes denaturalizing proteins and inactivating microbial toxins (Cohen \& Burns, 2004). Sodium hypochlorite $(\mathrm{NaOCl})$ and hydrogen peroxide $\left(\mathrm{H}_{2} \mathrm{O}_{2}\right)$ have been widely used as irrigants for root canal therapy being the first one the most important and irreplaceable because of its properties including tissue dissolving capacity and antimicrobial effect (Naenni et al., 2004). These desirable characteristics come mainly from oxidizing and hydrolyzing cell proteins, releasing chloride to form hypochlorous acid and its osmotic potential to extract liquids out of the cell (Di Lenarda et al., 2000).

On the other hand, hydrogen peroxide has disinfecting properties and it is used for root canal therapy as an irrigant solution in a concentration of $3 \%$. Its action mechanism comes by liberation of oxygen which is toxic for anaerobial microorganisms and by an effervescent reaction produced once it makes contact with organic tissue and certain chemical compounds. This reaction has been proposed to aid in the removal of debris from root canal walls (Ohara et al., 1993). 
Combined use of these irrigants $(\mathrm{NaOCl}$ and $\mathrm{H}_{2} \mathrm{O}_{2}$ ) is however, a matter of controversy. Grossman et al., (1988) indicate that the benefits from this combination are: a) effervescent reaction that produces removal of debris from root canal, b) dissolving capacity of organic tissue by sodium hypochlorite and c) disinfecting and bleaching action from both agents. Nevertheless, Baumgarther \& Mader (1987) report that sodium hypochlorite is more effective alone than in combination with hydrogen peroxide.

In this in vitro study the dissolution of connective tissue by the action of these irrigants was evaluated, both alone and combined, to determine if the speed of dissolution was affected.

\section{MATERIAL AND METHOD}

Seventy five pieces of fresh porcine muscle were cut at room temperature and their weight adjusted to $0.02 \mathrm{~g}$ with an analytic bascule (AS220/c/2, Radwag, Croatia, Poland) to be divided into five experimental groups.

A series of 120 Dappen glasses were prepared containing $1 \mathrm{ml}$ of an irrigating solution according to the experimental group assigned. For group 1, all the glasses contained $5 \%$ sodium hypochlorite. Group 2 glasses where filled with $2.5 \% \mathrm{NaOCl}$. In group 3 glasses where filled with either $2.5 \% \mathrm{NaOCl}$ or $3 \% \mathrm{H}_{2} \mathrm{O}_{2}$ and placed in alternated manner, with the first one at $2.5 \% \mathrm{NaOCl}$. For group 4 all glasses contained $\mathrm{H}_{2} \mathrm{O}_{2}$. Group 5 used saline $(0.9 \% \mathrm{NaCl})$ as negative control.

Every sample of tissue was then submerged in the test solution for a period of 1 minute (Fig. 1) then removed and immediately submerged in the next glass for the same period of time. This procedure was repeated until complete dissolution of the sample was observed and time passed was taken. For easier manipulation of the sample, it was pierced with an atraumatic half circle 5-0 suture needle.

The immersion time of the sample within the test solution was measured with an automatic recurring timer (G-8000G, Casio, Miami, E.E.U.U).

Statistical differences between groups were evaluated with ANOVA test for multiple measurements and Turkey's post hoc. $P$ value of $P<0.05$ was considered statistically significant.



Fig. 1. Sample tissue immersed in one of the irrigants.

\section{RESULTS}

Time required for complete dissolution of the sample was recorded for each group and the mean is shown in Table I. Group $1(5 \% \mathrm{NaOCl})$ was the fastest in dissolving the samples with a mean of 17.5 minutes. Group 2 was slower than 1 although the difference was not significant $(P=0.6)$. Time required for dissolution of samples in group 3 was significantly longer than that for groups 1 and $2(P<0.05)$ as shown in Figure 2 and Table I. Samples in group 4 turned into a white color after successive immersions in $3 \% \mathrm{H}_{2} \mathrm{O}_{2}$ but there was no tissue dissolution at all after 120 minutes. Group 5 didn't show either change or dissolution of the samples



Fig. 2. Mean time until complete dissolution of muscular porcine tissue for groups 1, 2 and 3 . 
Table I. Mean time until complete dissolution of the test sample.

\begin{tabular}{lcc}
\hline Group & Irrigant solution & Time in minutes $\left(^{*}\right)$ \\
\hline 1 & $\mathrm{NaOCl} 5 \%$ & $17.5(\mathrm{a})$ \\
2 & $\mathrm{NaOCl} 2.5 \%$ & $18.5(\mathrm{a})$ \\
3 & $\mathrm{NaOCl} 2.5 \%+\mathrm{H}_{2} \mathrm{O}_{2} 3 \%$ & $64.6(\mathrm{~b})$ \\
4 & $\mathrm{H}_{2} \mathrm{O}_{2} 3 \%$ & $>120(\mathrm{c})$ \\
5 & Saline & $>120(\mathrm{c})$ \\
\hline
\end{tabular}

(*) Different letters show statistical significant differences $(p<0.05)$.

\section{DISCUSSION}

Under the parameters of this study, the combination of sodium hypochlorite and hydrogen peroxide did not offer any benefit in terms of speed of dissolution of connective necrotic tissue. When the test sample from group $3(2.5 \% \mathrm{NaOCl}$ alternated with $3 \% \mathrm{H}_{2} \mathrm{O}_{2}$ ) was immersed in each of the irrigants, a strong effervescent reaction was observed around the specimen. However, it did not cause the disruption or disintegration of this organic tissue.

Comparing the time required for complete dissolution of connective tissue with sodium hypochlorite in different concentrations it was found that although $5 \% \mathrm{NaOCl}$ worked faster (Mean time $17.5 \mathrm{~min}$ ) the difference with $2.5 \%$ was not statistically significant (Mean time $18.5 \mathrm{~min})(P=0.6)$.

Caution must be taken when extrapolating data from in vitro studies. Factors like temperature, $\mathrm{pH}$, of the irrigant solution and buffer capacity of dentine may interfere with the effect of sodium hypochlorite in clinical environment (Hilgren et al., 2007; Cristensen et al., 2008) and they were not considered in this study. Furthermore, the test samples were completely immersed in the irrigating test solution which was exchanged every minute, something impossible to achieve during root canal therapy (Hasselgren et al., 1988).

Porcine muscular tissue has been previously used when evaluating sodium hypochlorite capability to dissolve necrotic connective tissue showing interesting results (Hasselgren et al.; Clarkson et al., 2006; Christensen et al.). Even though it has obvious histological differences with human pulp tissue, it provides an easy manipulation and standardization of the samples and also reproducible results.
The combination of sodium hypochlorite and hydrogen peroxide has been proposed for irrigation of root canals because it produces a transitory but strong effervescent reaction that is assumed should aid in the removal of debris and micro organisms from within the root canal (Shiozawa, 2000).

Shiozawa studying the chemical reaction between these two irrigating solutions found that the addition of hydrogen peroxide to sodium hypochlorite produces bubbles due to decomposition of $\mathrm{H}_{2} \mathrm{O}_{2}$ and the oxygen $\left(\mathrm{O}_{2}\right)$ release. This reaction decreases the $\mathrm{NaOCl}$ concentration making tissue dissolution less effective. The same author emphasizes that $\mathrm{NaOCl}$ toxicity for periapical tissues along with the potential damage caused by $\mathrm{O}_{2}$ release constitute a mayor problem when this irrigant combination is applied. The results from our study make it clear that the effervescence produced by this chemical reaction does not improve the dissolution capability of $\mathrm{NaOCl}$ in terms of necrotic connective tissue dissolution speed.

Although the combination of $\mathrm{NaOCl}$ and $\mathrm{H}_{2} \mathrm{O}_{2}$ has been used in clinical practice, evidence suggests that there is no benefit in the dissolution of connective tissue (Baumgarther \& Mader; Shiozawa), and considering the potential chemical irritation for periapical tissues added to the risk of causing emphysema (de Sermeño et al., 2009) it might seem reasonable to disregard the alternating use of these irrigants.

Toxicity of $\mathrm{NaOCl}$ is directly related with its concentration (de Sermeño et al.). Under the parameters of this study $5 \% \mathrm{NaOCl}$ was not significantly faster than $2.5 \%(P=0.6)$ in dissolving necrotic tissue. Therefore, $2.5 \%$ concentration could be considered as a good alternative for an irrigating solution with less toxicity and still good dissolving properties (Sánchez et al., 2009).

In conclusion, combination of $2.5 \% \mathrm{NaOCl}$ and $3 \% \mathrm{H}_{2} \mathrm{O}_{2}$ significantly delays the dissolution of necrotic muscle tissue and we do not recommend its use. $5 \% \mathrm{NaOCl}$ was the fastest irrigant solution in dissolving the test samples; nevertheless, $2.5 \% \mathrm{NaOCl}$ has lower irritation potential for periapical tissues and the difference in dissolution speed lacked statistical significance. 
ECHEVERRI, D. \& ACUÑA, C. Disolución de tejido conectivo en hipoclorito de sodio solo y en combinación con peróxido de hidrógeno al 3\%. Int. J. Odontostomat., 6(3):263-266, 2012.

RESUMEN: El objetivo fue evaluar la disolución de tejido muscular porcino por acción del hipoclorito de sodio en varias concentraciones y en combinación con peróxido de hidrógeno al $3 \%$. Se cortaron trozos de tejido muscular porcino y se ajustó su peso a $0,02 \mathrm{~g}$ para ser inmersos en $1 \mathrm{ml}$ de cada una de las soluciones de irrigación de prueba hasta observar la total disolución de la muestra. 75 piezas de tejido fueron divididas en 5 grupos y se utilizaron diferentes soluciones de irrigación como se describe: Grupo 1, hipoclorito de sodio al $5 \%$ ( $\mathrm{NaOCl} 5 \%$ ). Grupo 2, hipoclorito de sodio al 2,5\% ( $\mathrm{NaOCl} 2,5 \%$ ). Grupo 3, hipoclorito de sodio al 2,5\% alternado con peróxido de hidrógeno al 3\% ( $\left.\mathrm{NaOCl} 2,5 \%+\mathrm{H}_{2} \mathrm{O}_{2} 3 \%\right)$. Grupo 4, peróxido de hidrógeno al $3 \%\left(\mathrm{H}_{2} \mathrm{O}_{2}\right)$ y el grupo 5 utilizó solución salina ( $\mathrm{NaCl}$ 0,9\%) como control negativo. Para el hipoclorito de sodio al $5 \%$ la mediana del tiempo hasta la disolución total del tejido fue 17,5 minutos. La mediana del tiempo para el grupo 2 fue 18,5 para el grupo 3, 64,6 minutos y para los grupos 4 y 5 no se observó disolución del tejido de muestra tras 120 minutos. La significancia estadística se determinó con el test ANOVA multi muestra y se realizó test Tukey pos hoc con un nivel de significancia $\mathrm{P}=0,05$. Bajo los parámetros de este estudio no hubo diferencia significativa con el uso de hipoclorito de sodio al 2,5 y $5 \%$ en términos de velocidad de disolución del tejido conectivo $(P=0,6)$. La combinación de hipoclorito de sodio y peróxido de hidrógeno de forma alternada causó un retraso estadísticamente significativo en la disolución de tejido muscular porcino $(P<0,05)$. El uso alternado de hipoclorito de sodio y peróxido de hidrógeno no ofrece ningún beneficio en términos de velocidad de disolución de tejido conectivo necrótico.

PALABRAS CLAVE: hipoclorito de sodio, soluciones de irrigación, peróxido de hidrógeno.

\section{REFERENCES}

Andersen, M.; Lund, A.; Andreasen, J. O. \& Andreasen, F. M. In vitro solubility of human pulp tissue in calcium hydroxide and sodium hypochlorite. Endod. Dent. Traumatol., 8(3):1048, 1992

Baumgartner, J. C. \& Mader, C. L. A scanning electron microscopic evaluation of four root canal irrigation regimens. J. Endod., 13(4):147-57, 1987.

Christensen, C. E.; McNeal, S. F. \& Eleazer, P. Effect of lowering the $\mathrm{pH}$ of sodium hypochlorite on dissolving tissue in vitro. J. Endod., 34(4):449-52, 2008.

Clarkson, R. M.; Moule, A. J.; Podlich, H.; Kellaway, R.; Macfarlane, R.; Lewis, D. \& Rowell, J. Dissolution of porcine incisor pulps in sodium hypochlorite solutions of varying compositions and concentrations. Aust. Dent. J., 51(3):24551,2006

Cohen, S. \& Burns, R. Vías de la pulpa. $8^{\mathrm{a}}$ ed. Madrid, Mosby, 2004. pp.253-7.

de Sermeño, R. F.; da Silva, L. A.; Herrera, H.; Herrera, H.; Silva, R. A. \& Leonardo, M. R. Tissue damage after sodium hypochlorite extrusion during root canal treatment. Oral Surg. Oral Med. Oral Pathol. Oral Radiol. Endod., 108(1):e46-9, 2009.

Di Lenarda, R.; Cadenaro, M. \& Sbaizero, O. Effectiveness of 1 mol L-1 citric acid and 15\% EDTA irrigation on smear layer removal. Int. Endod. J., 33(1):46-52, 2000.

Hasselgren, G.; Olsson, B. \& Cvek, M. Effects of calcium hydroxide and sodium hypochlorite on the dissolution of necrotic porcine muscle tissue. J. Endod., 14(3):125-7, 1988.

Hata, G.; Hayami, S.; Weine, F. S. \& Toda, T. Effectiveness of oxidative potential water as a root canal irrigant. Int. Endod. J., 34(4):308-17, 2001.

Hilgren, J.; Swanson, K. M.; Diez-Gonzalez, F. \& Cords, B. Inactivation of Bacillus anthracis spores by liquid biocides in the presence of food residue. Appl. Environ. Microbiol., 73(20):6370-7, 2007.

Gulabivala, K.; Patel, B.; Evans, G. \& Ng, Y. Effects of mechanical and chemical procedures on root canal surfaces. Endod. Top., 10(1):103-22, 2005.

Grossman, L. I.; Oliet, S. \& Del Río, C. Endodontics. $11^{\text {a }}$ ed. Philadelphia, Lea and Febiger, 1988.

Naenni, N.; Thoma, K. \& Zehnder, M. Soft tissue dissolution capacity of currently used and potential endodontic irrigants. J. Endod., 30(11):785-7, 2004.

Ohara, P.; Torabinejad, M. \& Kettering, J. D. Antibacterial effects of various endodontic irrigants on selected anaerobic bacteria. Endod. Dent. Traumatol., 9(3):95-100, 1993.

Sánchez, F.; Furuya, A.; Arroniz, S.; Gómez, A. \& Gómez, L. Comparación de la acción bactericida de hipoclorito de sodio y Microcyn 60. Rev. Odont. Mex., 13(1):9-16, 2009.

Shiozawa, A. Characterization of reactive oxygen species generated from the mixture of $\mathrm{NaClO}$ and $\mathrm{H}_{2} \mathrm{O}_{2}$ used as root canal irrigants. J. Endod., 26(1):11-5, 2000.

Correspondence to:

Dr. Diego Echeverri Caballero

Profesor Asociado

Instituto de Odontoestomatología

Facultad de Medicina

Universidad Austral de Chile

Valdivia-CHILE

Email: di_echeverri@yahoo.es

Received: 17-05-2012 Accepted: 23-07-2012 